THE MAKING OF A

CHR I S T I A N ARISTOCRACY 

Michele Renee Salzman

\section{The Making of a Christian Aristocracy}

Social and Religious Change in the Western Roman Empire 
Copyright () 2002 by the President and Fellows of Harvard College All rights reserved

Printed in the United States of America

First Harvard University Press paperback edition, 2004

Library of Congress Cataloging-in-Publication Data

Salzman, Michele Renee.

The making of a Christian aristocracy : social and religious change in the western Roman Empire / Michele Renee Salzman.

p. $\mathrm{cm}$.

Includes bibliographical references (p. ) and index.

ISBN 0-674-00641-0 (cloth)

ISBN 0-674-01603-3 (pbk.)

1. Christian converts-Rome. 2. Aristocracy (Social class)-Religious life-Rome.

3. Sociology, Christian-History-Early church, ca. 30-600. I. Title.

BR195.C6 S35 2002

$270.2^{\prime} 086^{\prime} 21-d c 21 \quad 2001047075$ 
To my husband, Steven,

and my children, Juliana and Ben 
